\title{
CONSTITUTIONAL OBJECTIONS TO THE RAILWAY CONTROL ACT
}

\author{
Blewetr Lee \\ of the New York Bar
}

The Sixty-fifth Congress, to whom we are indebted for 'An Act to provide for the operation of transportation systems while under Federal control, for the just compensation of their owners, and for other purposes,' approved March 2I, I9I8, evidently were somewhat doubtful of the validity of the enactment, at least in part, for in the second section of the statute they provide that "The acceptance of any benefits under this section shall constitute an acceptance by the carrier of all the provisions of this Act".

What was it that set the wits of Congress to work to create this interesting provision to preserve, protect and defend the Constitution of the United States?

Was it Section Five of the Act? That section reads as follows:

"That no carrier while under Federal control shall, without the prior approval of the President, declare or pay any dividend in excess of its regular rate of dividends during the three years ended June thirtieth, nineteen hundred and seventeen: Provided, however, That such carriers as have paid no regular dividends or no dividends during said period may, with the prior approval of the President, pay dividends at such rate as the President may determine."

The purpose of this provision, it is stated in the Senate debate upon the Act, was to prevent violent fluctuations in the value of the stocks of the carriers and consequent speculation. In view of the public necessity of floating large investment loans for war purposes, possibly this provision may be considered as an exercise of the war power intended to protect the market for Government loans. It could hardly be sustained as a regulation of foreign or interstate commerce since carriers under Federal control are no longer engaged in such commerce.

It may well be that support can also be given to the first sentence of Section Seven of the Act which reads as follows:

"That for the purpose of providing funds requisite for maturing obligations or for other legal and proper expenditures, or for reorganizing railroads in receivership, carriers may, during the period of Federal control, issue such bonds, notes, equipment trust certificates, stock, and other forms of securities, secured or unsecured by mortgage, as the President may first approve as consistent with the public interest."

Since by Section Fourteen of the Act, Federal control of railroads is not to endure longer than one year and nine months next following 
the date of the proclamation by the President of the exchange of ratifications of the treaty of peace, the provision last quoted may also be supported as a reasonable regulation of the capitalization of a carrier preliminary to its engaging again in foreign and interstate commerce, and therefore a legitimate exercise of the commerce power of Congress.

Was it, then, the second sentence of Section Ten? This reads as follows:

"Actions at law or suits in equity may be brought by and against such carriers and judgments rendered as now provided by law; and in any action at law or suit in equity against the carrier, no defense shall be made thereto upon the ground that the carrier is an instrumentality or agency of the Federal Government."

This provision at least makes the carrier the instrumentality or agency of the Federal Government for purposes of legal procedure. The Government, so to speak, borrows the name of the carrier for convenience in carrying on litigation. A claim necessarily arises against the United States for any resulting damage to the carrier on account of the Government's taking the carrier's name in vain. Indeed, it may well be that any court in entering judgment would upon proper application confine the satisfaction of a judgment obtained against a carrier on account of an unlawful act for which not the carrier, but the Government was responsible, to the assets of the United States Railroad Administration. At any rate, a Court of Equity ought to grant relief in case the carrier's private assets are endangered by such a judgment. In the event of the return of the railroads to their former owners, the provision last quoted may give rise to very serious consideration, where litigation hangs over on account of causes of action arising during the period of Government control. Whether or not this provision of the statute is unconstitutional, it was very desirable that an order of the President through the Director General of Railroads should be made, putting an end to an arrangement so fraught with the possibility of grave practical injustice, by authorizing suits against the Director General instead of the carriers. Apparently this step is authorized by the first sentence of Section Ten of the Act, which reads as follows:

"That carriers while under Federal control shall be subject to all laws and liabilities as common carriers, whether arising under State or Federal Laws or at common law, except in so far as may be inconsistent with the provisions of this Act or any other Act applicable to such Federal control or with any order qf the President."

And such an order has in fact been made by the Director General. ${ }^{1}$

\footnotetext{
${ }^{2}$ General Order No. 50.
} 
None of the passages quoted so far seem to justify the elaborate precaution of requiring the carriers to "accept" the Act. There is another passage, however, which seems worthy of such foresight. The first three paragraphs of Section Six of the Act read as follows:

"That the sum of $\$ 500,000,000$ is hereby appropriated, out of any moneys in the Treasury not otherwise appropriated, which, together with any funds available from any operating income of said carriers, may be used by the President as a revolving fund for the purpose of paying the expenses of the Federal control, and so far as necessary the amount of just compensation, and to provide terminals, motive power, cars, and other necessary equipment, such terminals, motive power, cars and equipment to be used and accounted for as the President may direct and to be disposed of as Congress may hereafter by law provide.

"The President may also make or order any carrier to make any additions, betterments, or road extensions, and to provide terminals, motive power, cars and other equipment necessary or desirable for war purposes or in the public interest on or in connection with the property of any carrier. He may from said revolving fund advance to such carrier all or any part of the expense of such additions, betterments, or road extensions, and to provide terminals, motive power, cars, and other necessary equipment so ordered and constructed by such carrier or by the President, such advances to be charged against such carrier and to bear interest at such rate and be payable on such terms as may be determined by the President, to the end that the United States may be fully reimbursed for any sums so advanced.

"Any loss claimed by any carrier by reason of any such additions, betterments, or road extensions so ordered and constructed may be determined by agreement between the President and such carrier; failing such agreement the amount of such loss shall be ascertained as provided in section three hereof."

The reason for quoting the entire section is that the suggestion has been seriously made that the first paragraph of the section is limited to war emergencies. Since the period of Federal control may last for a year and nine months after the war, and since the money from the revolving fund is to be mixed with "funds available from any operating income of said carriers," and the revolving fund may be used for paying running expenses, and compensation to the carriers, as well as the purchase of terminals and equipment, it is impossible to sustain such an interpretation of the paragraph. Indeed the second paragraph quoted shows that the section is intended to go beyond the limits of the war power. Not only improvements "necessary or desirable for war pruposes," but others "in the public interest on or in connection with the property of any carrier" may be made by the President or ordered to be made by the carrier, and advances may be 
made from the revolving fund for such improvements "in the public interest," as well as those for war purposes.

It will be noted at the outset that there is no provision made for notice and a preliminary hearing as to whether or not the proposed improvement shall be made. Now, if the statute is construed to mean that the money for improvements made or ordered by the President shall first be advanced by him from the revolving fund, the constitutionality of the whole section is less open to doubt, for the carriers are given a remedy in case of loss, first by agreement with the President and failing that, a remedy before referees, and ultimately the Court of Claims, as provided by section three of the Act. It must still be conceded that the carrier may thus be compelled to pay for improvements made against its will, and to incur a debt without its consent of an amount and at a rate of interest over which it has no control. Suppose in fact there was, legally speaking, no loss, or no loss could be proved, the carrier might nevertheless, be still "improved out of its property" by constructions and purchases which it could not really afford. The improvements, as we have seen, might not necessarily be for war purposes; but even if they were, it cannot be constitutional for carriers to have loans forced on them in this way. If the improvements were for war purposes, all the less reason exists for compelling the carriers to borrow the money to make them from the Government upon the Government's terms. Carriers, especially when not engaged in business, are entitled to make the sacrifices of war upon the same terms as other people. When the time came to repay the principal or interest on the advances from the revolving fund, the non-consenting carrier would be in position to insist that its liability for the improvements should be decided under ordinary principles of the law of quasi-contracts and not on the basis of forced loans, to which it was not really a consenting party.

If, however, Section Six should be interpreted to mean that the carriers may be ordered by the President to make improvements at their own expense, finding the money themselves, without the money being advanced from the revolving fund, all without their consent and against their will, bearing in mind that the carriers are no longer engaged in business as such, or even in possession of their former properties, how can such a provision be defended ?2 If the carrier refused to make the improvement ordered, as depriving it of its property without due process of law, is there any court which would treat such an order as valid? As well might a statute provide that a man owning land near a munitions factory may be ordered to build a house for the benefit of the workers at a rent to be fixed by the President.

${ }^{2}$ See Missouri Pac. Ry. v. Nebraska (1910) 217 U. S. 196. 30 Sup. Ct. 46r; Oregon R. R. \& N. Co. v. Fairchild (1912) 224 U. S. 510, 32 Sup. Ct. 535. 
From a constitutional point of view, such a statute would be little improved by a provision that the President might build the house and make the owner pay back the expense so incurred with interest at a rate to be fixed by the President.

Assuming then that the doubt of Congress as to the constitutionality of this part of the Act which they were passing had a reasonable basis, let us now consider the effectiveness of the provision by which the doubt was to be cured. After providing for an agreement with a carrier for the use of its property during Government control, Section Two provides as follows:

"That if no such agreement is made, or pending execution of an agreement, the President may nevertheless pay to any carrier while under Federal control an annual amount, payable in reasonable installments, not exceeding ninety per centum of the estimated annual amount of just compensation, remitting such carrier, in case where no agreement is made, to its legal rights for any balance claimed to the remedies provided in Section Three hereof. Any amount thereafter found due such carrier above the amount paid shall bear interest at the rate of six per centum per annum. The acceptance of any benefits under this section shall constitute an acceptance by the carrier of all the provisions of this Act and shall .obligate the carrier to pay to the United States, with interest at the rate of six per centum per annum from a date or dates fixed in proceedings under section three, the amount by which the sums received under this section exceed the sum found due in such proceedings."

In weighing the persuasive power of this section it must be remembered that the Government nearly three months before its enactment had unexpectedly seized all the railroads of the country, their materials and supplies, their cash, the balances due them from their agents and conductors, almost everything they possessed, leaving their âebts, even those contracted for materials and supplies, unpaid. Practically every railroad company in the country was made insolvent at one stroke, and those lines which had recently used their credit in the public interest to purchase new equipment or enlarge their facilities, were in the most hopeless condition of all. Each company had a large mortgage indebtedness, interest on which was falling due from time to timè. Many companies had large outstanding issues of short term notes. The more fortunate ones had fixed periodical dividend dates when the reasonable demands of their stockholders for a return on their investment should be met. Without aid from some quarter, ruin stared every company in the face. Since the seizure of their property, their credit was so impaired that it was practically impossible to procure, except from the Government, sufficient funds for their pressing necessities.

Section Two of the Act offered the one way of relief. The Presi- 
dent, pending an agreement, might pay not exceeding ninety per cent of the estimated annual amount of just compensation, while the carrier was pressing its slow and tortuous remedy against the Government provided by Section Three of the Act, the only certain thing in regard to which was that the carrier would be hopelessly ruined before it ever got its money. The President was not bound to pay ninety per cent; he might pay less, or pay nothing at all, but whatever he did pay was not to be more than ninety per cent of what the statute had declared by the first paragraph of the Act to be "just compensation." Section Two provides that acceptance of any benefits under this section shall constitute an acceptance by the carrier of all the provisions of this Act. Suppose the President paid something to the carrier as an advance upon its just compensation, any amount, and the carrier took it, could the carrier afterwards contest the constitutionality of any part of the Act?

It should be borne in mind that this is not the ordinary case of estoppel to set up the unconstitutionality of an act after taking advantage of it-it is the case of an act, of which a separable part, the statute dealing with many different and distinct subjects, is probably unconstitutional, but such part is disconnected from the other parts of the act which deal with such other subjects and are of unquestionable validity. The acceptance clause undertakes to protect not the portion of the act under which a benefit is taken, but to protect a disconnected and probably unconstitutional part of the act dealing with a different subject, and under which no benefit is taken. To illustrate, if a carrier should voluntarily borrow the money from the Government under Section Six, to make improvements, the carrier could not be heard to contend that Section Six was unconstitutional. But it does not follow that because a carrier accepts from the Government part of the compensation which the Government already owes the carrier, the carrier thereby binds itself to obey any order the President chooses to make in the future in regard to improvements.

The significant features of the supposed acceptance are first that the Government already owes the carrier more than the amount the carrier receives, and secondly that the carrier is compelled to take the money by virtue of a necessity which the Government has itself created. If anyone but a railroad company, which may be safely regarded from a political point of view as the common enemy and oppressor of all, were required by law to surrender his constitutional rights under pressure of this kind, the spectacle would not be considered edifying. Suppose the Government should commandeer a flock of one hundred sheep and require the impoverished shepherd to sign a release of all damages in consideration of receiving back ninety of the sheep, would any court sustain the validity of the instrument? Would it be any stronger if the return of ninety of the sheep were made the consideration not of a release but of an agreement that the 
Government should thereafter have the right from time to time to help itself to sheep whenever it saw fit?

The Government acting from the loftiest motives, let us say, but forcibly, takes away from the corporation practically everything it possesses, leaving it heavily in debt, and then undertakes to purchase immunity from liability for future acts otherwise unlawful, by returning part of what the Government has taken from or owes to the impoverished and insolvent sufferer from such seizure. Let us assume the act of the Government to be prompted by the most patriotic zeal, the injustice of the deed is none the less.

We submit therefore that the supposed acceptance of the statute is made under undue pressure, that no real consent lies at the basis of the supposed waiver of constitutional rights, that no real consideration is received by the corporation therefor.

Another weakness of the supposed "acceptance" of the act is that it is a waiver not only of past breaches, if any, of constitutional rights, but much more a consent to possible wrongs to be committed in future. Once the corporation has taken its King's Shilling, according to this statute, it is bound to obey all future orders of the President to make any additions, betterments, or road extensions, and to provide terminals, motive power, cars or equipment necessary or desirable for war purposes or in the public interest on or in connection with its own property. This is no estoppel, or waiver; it is the grant of an indulgence to deprive the carrier of its property without due process of law in future with impunity. If statutes can be exempted from the test of constitutionality by this device, is its discovery a matter for congratulation?

Before leaving the subject, it may be worth while to point out that while Section Two speaks of the acceptance of "any benefits," the actual benefits contemplated by the section are not arbitrary doles or crumbs from the Government's table. In the first place an amount is to be paid, not lent. It is to be an annual amount, that is to say, a sum repeated from year to year during Federal control, the propriety of which is therefore tu be judged not by one year, but by the series of years the control lasts. It is to be paid in reasonable installments, and manifestly an installment is not reasonable unless both in time and in amount it is reasonable. If all the installments are to be reasonable their aggregate constituting the "annual amount" must-also be reasonable. In order to decide whether an amount is reasonable, it must be considered whether it is fairly adequate. The "annual amount" is intended by Congress to be substantial-the allowance, in express terms, of as much as ninety per cent of the "just compensation," or Standard Return, provided in the first paragraph of the first section of the Act clearly indicates as much. The holding back of ten per cent or more of the estimated just compensation is obviously for the purpose of protecting the Government against loss, not of furrishing 
the means of putting financial pressure on the carrier to compel it to submit to whatever conditions the Government chooses to impose. For purposes of statutory construction, the Government must be assumed to be honest. Subject to the limit of ninety per cent as provided, a carrier is to get a reasonable return for its property, otherwise it has not received the benefits which Congress evidently intended to be given under the Section. In no point of view then can it be properly contended that a carrier has lost the protection of the Fifth Amendment, because it has received interest-bearing loans from the Government with or without collateral, or irregular payments as advances upon the carrier's "just compensation" which were not reasonable installments of an annual amount fairly substantial in view of the earning value of the property.

It may be of interest to add that the third section of the standard agreement between the Director General of Railroads and the various carriers begins as follows: "The Company accepts all the terms and conditions of the Federal Control Act." In view of the abundant new considerations contained in the proposed standard agreement, no reason occurs why the contract, once executed, will not fully accomplish the purpose of laying the ghost of the serious constitutional question above discussed. 